\title{
Mapping and validation of Xanthomonas citri subsp citri genes regulated by putative plant- inducible promoter box (PIP-box)
}

\author{
F.M.S. Carvalho ${ }^{1,2}$, J.C.F. Oliveira ${ }^{1,3}$, M.L. Laia ${ }^{1,4}$, T.R. Jacob ${ }^{1,2}$, \\ R.M. Ferreira ${ }^{1}$, M.I.T. Ferro ${ }^{1}$, R.I.D. Tezza ${ }^{1,6}$, S.M. Zingaretti ${ }^{1,5}$, \\ C.F. Silva ${ }^{1}$ and J.A. Ferro ${ }^{1,6}$
}

'Laboratório de Bioquímica e Biologia Molecular, Departamento de Tecnologia, Faculdade de Ciências Agrárias e Veterinárias, Universidade Estadual Paulista, Jaboticabal, SP, Brasil

${ }^{2}$ Departamento de Genética, Faculdade de Medicina de Ribeirão Preto, Universidade de São Paulo, Ribeirão Preto, SP, Brasil

${ }^{3}$ Departamento de Ciências Biológicas, Universidade Federal de São Paulo, Diadema, SP, Brasil

${ }^{4}$ Departamento de Engenharia Florestal, Faculdade de Ciências Agrárias, Universidade Federal dos Vales do Jequitinhonha e Mucuri, Diamantina, MG, Brasil

${ }^{5}$ Unidade de Biotecnologia, Universidade de Ribeirão Preto, Ribeirão Preto, SP, Brasil

${ }^{6}$ Centro de Recursos Biológicos e Biologia Genômica,

Faculdade de Ciências Agrárias e Veterinárias, Universidade Estadual Paulista, Jaboticabal, SP, Brasil

Corresponding author: F.M.S. Carvalho

E-mail: flaviasc2@hotmail.com

Genet. Mol. Res. 15 (2): gmr.15028428

Received: January 12, 2016

Accepted: March 11, 2016

Published: May 6, 2016

DOI http://dx.doi.org/10.4238/gmr.15028428

ABSTRACT. Citrus canker, caused by the Gram-negative bacterium Xanthomonas citri subsp citri (Xac), is a major disease affecting citriculture worldwide, because of the susceptibility of the host and the 
lack of efficient control methods. Previous studies have reported that some genes of phytopathogenic bacteria possess a consensus nucleotide sequence (TTCGC...N15...TTCGC) designated the "plant-induciblepromoter box" (PIP box) located in the promoter region, which is responsible for activating the expression of pathogenicity and virulence factors when the pathogen is in contact with the host plant. In this study, we mapped and investigated the expression of 104 Xac genes associated with the PIP box sequences using a macroarray analysis. Xac gene expression was observed during in vitro (Xac grown for 12 or $20 \mathrm{~h}$ in XAM1 induction medium) or in vivo (bacteria grown in orange leaves for 3 to 5 days) infection conditions. Xac grown in non-induction NB liquid medium was used as the control. cDNA was isolated from bacteria grown under the different conditions and hybridized to the macroarray, and 32 genes differentially expressed during the infection period (in vitro or in vivo induction) were identified. The macroarray results were validated for some of the genes through semi-quantitative RT-PCR, and the functionality of the PIP box-containing promoter was demonstrated by activating $\beta$-glucuronidase reporter gene activity by the PIP boxcontaining promoter region during Xac-citrus host interaction.

Key words: PIP-Box promoter; Gene reporter $\beta$-glucuronidase; Citrus canker; Xanthomonas citri; XAMI induction medium

\section{INTRODUCTION}

Xanthomonas citri subsp citri (Xac), a Gram-negative bacterium, is the etiological agent of citrus canker, a disease that attacks citrus crops worldwide, causing significant yield and economic losses (Agrios, 2005). Xac colonizes the plant surface as an epiphyte without causing disease, until entering the host through natural openings (stomata, hydathodes) or wounds; subsequently, Xac triggers the expression of pathogenicity and virulence-related genes that facilitate the adaptation of the bacterium to the host, and induces the eventual attack of the bacterium. To develop in the apoplast, this phytobacterium has to coordinate its adaptation to the host environment and cellular multiplication, with the induction of genes required for successful infection (Brown, 2001).

Almost all Gram-negative phytopatogenic bacteria carry a type III secretion system (TTSS). Xanthomonas spp. presents a TTSS, encoded by a cluster of hypersensitive reaction and pathogenicity ( $h r p$ ) genes, which is a critical pathogenicity factor (Guo et al., 2012a). Two regulators control the expression of the $h r p$ genes: HrpG, a member of the OmpR regulator family, and HrpX, an AraC-type transcriptional activator. Under an environmental stimulus, HrpG becomes phosphorylated and activates the expression of $h r p X$ and $h r p A$ (Wengelnik and Bonas, 1996). HrpX controls the expression of other hrp genes as well as other effector genes. The AraC-type DNA binding domain present in HrpX specifically recognizes a regulatory element called plant-inducible promoter box (PIP-box), present in the cis-regulatory region of the hrp gene cluster (Wengelnik and Bonas, 1996; Koebnik et al., 2006).

The PIP-box was first described in Xanthomonas campestris pv. vesicatoria $(X c v)$ with a consensus sequence motif TTCGC...N15...TTCGC (Fenselau and Bonas, 1995; Koebnik et 
al., 2006). This consensus sequence is called a canonical or perfect PIP-box (Ciesiolka et al., 1999; Koebnik et al., 2006). A putative PIP-box region has also been identified in the promoter region of avrRxv, the avirulence gene from $X c v$, indicating that this gene can be regulated like the hrp genes (Ciesiolka et al., 1999). Similarly, the PIP-box has also been identified in the promoter regions of avirulence genes of another phytopathogen, Ralstonia solanacearum (Salanoubat et al., 2002).

Imperfect PIP-box sequences have been described in various other phytopathogens. In R. solanacearum, the PIP-box sequence TTCG....N16....TTCG, originally named hrpII box, was found to be essential for the activation of $h r p Y$ (Cunnac et al., 2004). In Xcv, the imperfect PIP-box sequence TTCGC....N8....TTCGT regulates the expression of $h r p F$ (Huguet and Bonas, 1997). Recently, another imperfect PIP-box TTCGA....N21....TTCGC was described in the promoter region of the gene kgtP in Xanthomonas orizae pv. orizae (Guo et al., 2012b). $\mathrm{KgtP}$ is secreted by the TTSS, and its expression is positively regulated by HrpX and HrpG.

Therefore, PIP-box and PIP-box-like sequences are believed to play pivotal roles in the regulation of plant-pathogen interactions by regulating the gene expression (Figueiredo et al., 2011). Herein, we aimed to identify new genes in Xac that are regulated by the PIP-box and PIP-box-related sequences, and to relate them to putative pathogenicity and virulence functions underlying citrus canker.

To this end, an in silico search was done in the genomic sequence using the sequence motifs TTCGN...N15...TTCGN and TTCGC...N16...TTCGC, and 104 PIP-box sequences were mapped throughout the genome of Xac 306. The functionality of these putative PIPregulated genes was addressed by a macroarray assay, wherein the membrane was probed against cDNA from non-infecting and infecting Xac at 12, 20, 72, and $120 \mathrm{~h}$ after inoculation.

The results presented herein show that all PIP-box-containing genes, such as effectors, hrp genes, and non-TTSS-related genes, showed altered expression (up and down) during the initial stages of Xac infection in vitro and in vivo.

\section{MATERIAL AND METHODS}

\section{Strain, plasmids, and culture medium}

The strains and plasmids used in this study are listed in Table 1. Xac strain 306, which is primarily used for phytopathogen sequencing, was cultured. A cell culture in the log phase was obtained by incubating the induction culture in the non- $h r p$-inducing NB medium ( $5 \mathrm{~g}$ peptone and $3 \mathrm{~g}$ beef extract for a total volume of $1000 \mathrm{~mL}$ ), or in the $h r p$-inducing XAM1 medium [7.57 mM $\left(\mathrm{NH}_{4}\right)_{2} \mathrm{SO}_{4}, 33.06 \mathrm{mM} \mathrm{KH}_{2} \mathrm{PO}_{4}, 60.27 \mathrm{mM} \mathrm{K}_{2} \mathrm{HPO}_{4}, 1.6 \mathrm{mM}$ sodium citrate $\left(\mathrm{C}_{6} \mathrm{H}_{5} \mathrm{Na}_{3} \mathrm{O}_{7} .2 \mathrm{H}_{2} \mathrm{O}\right)$, $0.5 \mathrm{mM}$ fructose, $0.5 \mathrm{mM}$ sucrose, $1 \mathrm{mg} / \mathrm{mL}$ bovine serum albumin (BSA), $1 \mathrm{mM} \mathrm{MgSO}{ }_{4}$, and $0.03 \%$ Casamino acid; $\mathrm{pH}=5.4]$, in a shaker incubator at $28^{\circ} \mathrm{C}$ for $16-20 \mathrm{~h}$. Electrocompetent Escherichia coli DH10B (Eppendorf AG, Hamburg, Germany) cells were cultured at $37^{\circ} \mathrm{C}$ in Luria Bertani (LB) culture medium, and electrocompetent Xanthomonas axonopodis pv. citri cells were grown at $28^{\circ} \mathrm{C}$ in NB medium for $16 \mathrm{~h}$. The culture media were supplemented with the antibiotics ampicillin $(100 \mu \mathrm{g} / \mathrm{mL})$ and spectinomycin $(50 \mu \mathrm{g} / \mathrm{mL})$, when necessary.

\section{In silico mapping of PIP-box sequences}

Possible PIP-box promoters and other associated genes were mapped using the Perl programming language (http://www.perl.org). PIP-box consensus sequences with 15 to 16 
F.M.S. Carvalho et al.

nucleotide intervals (5'-TTCGN...N15...TTCGN-3' and 5'-TTCGC...N16...TTCGC-3') were mapped from a -1000 to -10 nucleotide interval towards the 5 '-open reading frame (ORF). For the 15-nucleotide interval PIP motif, degenerated positions were defined for the four bases (adenine, guanine, thymine, or cytosine). Therefore, the fifth consensus base for 5'-TTCGN... N15...TTCGN-3' was considered to be degenerated for the DNA strand. In silico mapping of possible PIP-box sequences yielded 104 PIP motifs associated to clones representing ORFs that could possibly be related to the PIP-box regulation.

Table 1. Bacterial strains and plasmids used in this study.

\begin{tabular}{|c|c|c|}
\hline Strain or plasmid & Characteristics & Reference or source \\
\hline X. axonopodis pv. citri & & Da Silva et al., 2002 \\
\hline E. coli $\mathrm{DH} 10 \mathrm{~B}$ & & Eppendorf AG \\
\hline \multicolumn{3}{|l|}{ Plasmids } \\
\hline pBluescript II SK (+) & Phagemid, pUC derivative, $\mathrm{Am}^{\mathrm{r}}$ & Stratagene \\
\hline pHM1 & Broad-host-range cosmid vector, $\mathrm{pSa}$ ori, $\mathrm{Sp}^{\mathrm{r}} / \mathrm{Sm}^{\mathrm{r}}$ & Innes et al., 1988 \\
\hline pBGUS & gus gene in pBluescript II SK $(+)$ & This study \\
\hline pBGUS0424 & XAC0424 promoter region is inserted downstream to the gus gene in pBGUS & This study \\
\hline pBGUS0416 & XAC0416 promoter region is inserted downstream to the gus gene in pBGUS & This study \\
\hline pBGUS2370 & XAC2370 promoter region is inserted downstream to the gus gene in pBGUS & This study \\
\hline pHMGUS (negative control) & gus gene in $\mathrm{pHM} 1$ & This study \\
\hline pHMGUS/500 (negative control) & $\begin{array}{l}\text { 500-bp fragment from a non-promoter region subcloned downstream to the gus } \\
\text { methionine in the pHMGUS }\end{array}$ & This study \\
\hline pHMGUS0424 & pBGUS0424 region of interest (XAC0424 promoter $+g u s$ ) subcloned to pHM1 & This study \\
\hline pHMGUS0416 & pBGUS0416 region of interest (XAC0416 promoter + gus) subcloned to pHM1 & This study \\
\hline pHMGUS2370 & pBGUS2370 region of interest (XAC2370 promoter + gus) subcloned to pHM1 & This study \\
\hline
\end{tabular}

\section{Selection of representative clones for construction of PIP-box-associated ORF macroarray}

Shotgun clones used for Xac genome sequencing, which contained ORFs associated with PIP-box elements, were recovered and rearranged on 96-well plates. DNA of recombinant plasmids containing the ORFs of interest was extracted from $E$. coli, and the identity of each clone was verified by automated sequencing. Plasmid DNA was prepared using a previously described alkaline lysis method (Sambrook et al., 1989). Plasmid DNA was sequenced according to the dideoxynucleotide chain termination method (Sanger et al., 1977) via a polymerase chain reaction (PCR) using a "BigDye Terminator" (Applied Biosystems, Foster City, CA, USA) and an M13 forward and reverse primer for the validation of each clone.

\section{Xac macroarray membranes}

Plasmid DNA expressing the 208 ORF sequences were printed on nylon membranes from the 96-well plates (Raybond-N+; Amersham Biosciences, Amersham, UK) using a Q-Bot robot (Genetix). The samples were spotted in duplicate (technical replicates); each clone was deposited thrice at the same point to ensure sample placement. A 900-micron spacing was maintained between each point in a $3 \times 3$ array. The DNA samples were then fixed to the membrane using a UV light $\left(1600 \mathrm{~J} / \mathrm{cm}^{2}\right)$.

\section{Preparation of infectious Xac}

The expression of 104 Xac PIP-associated genes in XAM1 virulence induction medium 
was evaluated at 12 and $20 \mathrm{~h}$. In planta virulence was analyzed at $72 \mathrm{~h}$ (3 days) and $120 \mathrm{~h}$ (5 days) after inoculation. Leaves from host citrus plants (Citrus sinensis) were inoculated using the pressure infiltration method, such that the entire leaf was completely infiltrated with Xac at a concentration of $10^{8} \mathrm{CFU} / \mathrm{mL}$. Approximately 100-150 leaves were inoculated in order to obtain a pellet of infecting Xac for a given condition. Bacterial cells were recovered from the leaves of inoculated host plants by cutting with scissors and submerging in a $0.85 \%$ $\mathrm{NaCl}$ solution for 15 minutes under agitation in an ice/water bath. The inoculated plants were maintained in a biosafety laboratory under optimal temperature, luminosity, and humidity conditions, and with HEPA air filtering equipment in order to contain the phytopathogen.

\section{Probes, macroarray hybridization, and analysis}

Total RNA was extracted from Xac cells using a standard Trizol ${ }^{\circledR}$ reagent (Life Technologies, Carlsbad, CA, USA) according to manufacturer protocols, and treated with amplification grade deoxyribonuclease I (Invitrogen; Life Technologies) according to the manufacturer specifications. cDNA probes of non-infecting and infecting Xac were obtained by reverse transcription with the non-specific hexa-oligonucleotides primer $\operatorname{pd}(\mathrm{N}) 6$ and $\left[{ }^{33} \mathrm{P}-\right.$ $\alpha] \mathrm{dCTP}$ (Amersham Biosciences).

\section{Synthesis of cDNA probe and membrane hybridization}

cDNA probes were synthesized from total RNA extracted from the bacteria at infecting and non-infecting stages of growth (at different times). Six independent biological replicates representing the various conditions were used to obtain total RNA for macroarray assays (which justifies the inoculation of a large number of orange leaves in this study). Two technical replicates were used in membrane hybridization.

The cDNA probes were designed as described by Schummer et al. (1999). Total RNA $(30 \mu \mathrm{g})$ and the random primer $\mathrm{pd}(\mathrm{N}) 6(156 \mathrm{pmol})$ were incubated at $75^{\circ} \mathrm{C}$ for $10 \mathrm{~min}$ and subsequently cooled on ice. The reaction mixture, composed of $5 \mu \mathrm{L}$ standard 5X First Strand Buffer (Invitrogen); $2.5 \mu \mathrm{L}(100 \mathrm{mM})$ 1,4-dithiothreitol (Invitrogen); $80 \mathrm{U}$ RNAseOUT (Invitrogen); unlabeled dATP, dTTP, and dGTP $\left(10 \mathrm{mM}\right.$ each); and $3 \mu \mathrm{L}\left[\alpha^{33} \mathrm{P}\right] \mathrm{dCTP}(30$ $\mu \mathrm{Ci}$ ), was incubated at $42^{\circ} \mathrm{C}$ for $5 \mathrm{~min}$. SuperScript III RNase $\mathrm{H}^{-}$Reverse Transcriptase (250 $\mathrm{U}$; Invitrogen) was added to the reaction mixture, and the resulting mixture was incubated at $25^{\circ} \mathrm{C}$ for $30 \mathrm{~min}$. Subsequently, $12.5 \mathrm{mM}$ dCTP was added to the reaction mixture and was incubated at $25^{\circ} \mathrm{C}$ for $2 \mathrm{~h}$. The probe was denatured at $95^{\circ} \mathrm{C}$ for $5 \mathrm{~min}$. The reaction was stopped with a $50-\mathrm{mL}$ mixture containing $1.4 \mathrm{~mL} 5 \mathrm{M} \mathrm{NaOH}, 1.8 \mathrm{~mL} 3.9 \mathrm{M} \mathrm{HCl}, 7.0 \mathrm{~mL} 1 \mathrm{M}$ Tris- $\mathrm{HCl}, \mathrm{pH} 7.5$, and sterilized water. The probe was purified with Sephadex G-50 columns (Invitrogen), and the incorporation of radioactive compounds was measured by a standard scintillation counter (LS6500; Beckman Coulter, Brea, CA, USA), in order to compare the utilization of cDNA probes against the incorporated amount of radioactive compounds.

Labeled cDNA were hybridized to macroarray membranes in a solution containing 1\% (w/v) BSA (BSA Fraction V; Sigma-Aldrich, St. Louis, MA, USA), $1 \mathrm{mM}$ ethylenediaminetetracetic acid, 7\% sodium dodecyl sulfate (SDS; $99.9 \%$ purity), and $0.5 \mathrm{M}$ sodium phosphate $\left(\mathrm{Na}_{2} \mathrm{HPO}_{4}\right)$ at $58^{\circ} \mathrm{C}$ for $18 \mathrm{~h}$. The membranes were then washed twice in 2X SSC and $0.1 \%$ SDS at $65^{\circ} \mathrm{C}$ for $15 \mathrm{~min}$; once in $1 \mathrm{X} \mathrm{SSC}$ and $0.1 \% \mathrm{SDS}$ at $65^{\circ} \mathrm{C}$ for 15 min; twice in $0.1 \mathrm{X} \mathrm{SSC}$ and $0.1 \% \mathrm{SDS}$ at $65^{\circ} \mathrm{C}$ for $15 \mathrm{~min}$; and once in $0.1 \mathrm{X} \mathrm{SSC}$ at $25^{\circ} \mathrm{C}$ 
for $5 \mathrm{~min}$. The filters were sealed with plastic film and exposed to imaging plates (Fujifilm, Tokyo, Japan) for $96 \mathrm{~h}$. The images of the membranes were scanned using Phosphorimager FLA3000-G (Fujifilm), which produces a digital image of the radioactive signal.

\section{Statistical analyses}

Hybridized macroarray image files were evaluated using the ArrayVision_software (Imaging Research, Ontario, Canada) and the data were analyzed using the R statistical platform (http://www.R-project.org; Ihaka and Gentleman, 1996). The data were first normalized using the "vsn" package (Huber et al., 2002). Differentially expressed genes were obtained using the "limma" package (Smyth, 2005). The genes were classified in decreasing order from the B-statistic considering the false discovery rate (FDR) proposed by Benjamini and Hochberg (1995) and analyzed using the limma package. A list of differentially expressed genes with a $5 \%$ FDR, B-statistic $>0$, and $\mathrm{P}$ value $<0.05$ was obtained. The gene expression pattern over time was determined using the "timecourse" package (Tai and Speed, 2006). All packages used in this study belong to the Bioconductor (Gentleman et al., 2004) project.

\section{Semi-quantitative RT-PCR}

Total RNA obtained from samples cultured in different conditions $(\mathrm{N}=6)$ were used for macroarray analysis and later pooled together only to perform semi-quantitative RTPCR experiments in three technical replicates. Three differentially expressed genes (ORFs XAC0398, XAC0416, and XAC2370) and an internal control showing constitutive expression (rDNA 16S) were validated through semi-quantitative RT-PCR. The oligonucleotides used in this experiment are listed in Table 2. These RNA samples were treated with DNase and run as controls. RT-PCR was conducted using the standard SuperScript ${ }^{\mathrm{TM}}$ One-Step RT-PCR with Platinum $\mathrm{Taq}^{\mathbb{B}} \mathrm{kit}^{\mathrm{P}}$ (Invitrogen) according to the manufacturer protocols. Two hundred and fifty nanograms of DNase-treated RNA was used as the template, and 20 reaction cycles were performed in a Mastercycler Gradient thermal cycler (Eppendorf). The resulting products were electrophoresed on agarose gels, and the bands were transferred to a nylon membrane via a standard Southern blot (Sambrook et al., 1989). Probes corresponding to the purified PCR fragments from the same genes used in RT-PCR (ORFs XAC0398, XAC0416, and XAC2370), labeled with a commercial kit (Gene Images AlkPhos Direct Labeling and Detection System; Amersham Biosciences), were hybridized to the nylon membranes and subsequently exposed to X-ray films (MXG/Pluys; Kodak, Rochester, NY, USA). The autoradiographs were subsequently scanned and quantified densitometrically using a Shimadzu CS-9301 analyzer (Shimadzy Medical Systems, Kyoto, Japan).

\section{Gene reporter assays}

Xac strains harboring reporter constructions and non-transformed Xac (control) were grown for $20 \mathrm{~h}$ in XAM1 or NB medium and subsequently assayed in vitro. The $\beta$-glucuronidase (GUS) assay was performed as described by Lacorte (1998). In planta assays were performed by inoculating reporter Xac strains into citrus host leaves and bacterial cells were exuded from the vegetal tissue 3 to 5 days after inoculation. Bacterial pellets obtained from plants cultivated under different conditions were re-suspended in $1 \mathrm{mM} \mathrm{MgCl}_{2}$ solution until an optical density 
$\left(\mathrm{OD}_{600 \mathrm{~nm}}\right)$ of 0.3 was attained. Aliquots $(100 \mu \mathrm{L})$ of this solution were used for enzymatic assays, which were performed in triplicate. The Xac samples were cultured in X-gluc buffer or in X-gluc buffer with the $\mathrm{X}$-gluc substrate; the absorbance of these samples at $\mathrm{OD}_{600 \mathrm{~nm}}$, as well as the color change in the solutions, were observed. The absorbance values of the bacterial cells in the X-gluc buffer were subtracted from the values of the respective bacterial cells in the X-gluc buffer $+\mathrm{X}$-gluc (substrate). The constructed plasmids are listed in Table 1. A 1.8-kb BamHI-SacI fragment containing the gus gene cloned to the $\mathrm{pBin}$ vector (Frisch et al., 1995) was ligated to the pBluescript II SK vector (Stratagene, San Diego, CA, USA), which was digested with the same enzymes, thereby generating the pBGUS vector. EcoRI- and BamHI-containing primers were designed (Table 2) to amplify fragments encompassing the promoter regions of the XAC0416 (500 bp) and XAC0424 (500 bp) ORFs, which were cloned to pBGUS (as they could be treated with the same enzymes), generating the pBGUS0416 and pBGUS0424 constructs, respectively. The promoterless pBGUS vector was used as the control. HindIII-SacI fragments excised from pBGUS0416 and pBGUS0424, each containing a Xac promoter at the 5'-end of the gus gene, were cloned to the Xanthomonas expression vector pHM1 (Innes et al., 1988), which could be digested with the same endonucleases, generating the pHMGUS0416, pHMGUS0424, and pHMGUS constructs. All constructs were confirmed by a restriction map analysis in order to verify the cloning process.

Table 2. Primers used to amplify open reading frames (ORFs) in semi-quantitative reverse transcriptase polymerase chain reaction (RT-PCR) amplification of the promoter regions.

\begin{tabular}{|c|c|c|c|}
\hline Primer* & Sequence $\left(5^{\prime}-3^{\prime}\right) * *$ & Restriction site*** & Amplified fragment length**** \\
\hline XAC0398 (F) & GATACGGTCACCCAAGATATG & - & \multirow[t]{2}{*}{209} \\
\hline XAC0398 (R) & ATGTGCGCGACGATGTTG & - & \\
\hline $\mathrm{XAC} 0416(\mathrm{~F})$ & GCGCCAACTCGTCCTTCTTTC & - & \multirow[t]{2}{*}{302} \\
\hline XAC0416 (R) & AAGCCACCACCATTCTGC & - & \\
\hline $\mathrm{XAC} 2370(\mathrm{~F})$ & TAGTGATTACCGACGTGC & - & \multirow[t]{2}{*}{942} \\
\hline XAC2370 (R) & ACAGGTTACGGATTGCTG & - & \\
\hline XAC4291 (F) & TAAGTGAAGAGTTTG & - & \multirow[t]{2}{*}{800} \\
\hline XAC4291 (R) & AGGGTATCTAATCCTGTTTG & - & \\
\hline PXAC0416 (F) & CGGGGATCCATGACGATTCCTCTCTGA & BamHI & \multirow[t]{2}{*}{500} \\
\hline PXAC0416 (R) & TAAGAATTCCTGCCCGACGACCACATC & EcoRI & \\
\hline PXAC0424 (F) & AAAGGATCCGCGCCAGGGTCTCGAGAG & BamHI & \multirow[t]{2}{*}{500} \\
\hline PXAC0424 (R) & CGAGAATTCCATGGCAACCATCTAAAC & EcoRI & \\
\hline PXAC2370 (F) & GAAGAATTCAGCATGTGACGAT & EcoRI & \multirow[t]{2}{*}{380} \\
\hline PXAC2370 (R) & GCCGGATCCTATTATCTTAAC & Bam HI & \\
\hline
\end{tabular}

*F, forward; $\mathrm{R}$, reverse. ${ }^{* *}$ Bold letters represent introduced restriction sites. ${ }^{* * *}$ Introduced restriction recognition sites. ****Length of a fragment (bp) downstream of the initiation codon (deduced promoter region) and including a putative plant-inducible promoter.

\section{RESULTS}

Xac PIP-box-regulated genes that were differentially expressed during in planta infection were identified by in silico mapping of the PIP-box-like sequences and its associated genes throughout the genome.

\section{In silico mapping of genes containing PIP-box promoters}

The whole genome sequence of Xac 306 was mined for PIP-box candidates. An in silico search identified 104 PIP-boxes in the Xac 306 genome, with 89 presenting the 
5'-TTCGN...N15...TTCGN-3' consensus and 15 presenting the 5'-TTCGC...N16...TTCGC-3' consensus sequences. These PIP-associated genes were categorized according to the genome annotation of the strain ( $\underline{\text { S1 Table }})$.

\section{Macroarray hybridization and identification of differentially expressed genes}

Xac genes, expressions of which are regulated by Xac putative PIP-box sequences during infection, were identified using a macroarray containing 104 putative PIP-box sequences and genes that could be regulated by these sequences. The genes were hybridized with cDNA extracted from infecting and non-infecting Xac (during different times of infection) and 32 differentially expressed genes were identified (Tables 3 and 4). These genes showed different expression profiles: 12 of these genes were upregulated, while the remaining 19 were downregulated (Tables 3 and 4). The expression of some genes increased or decreased with respect to the infection time; however, the expression of only one gene increased and decreased during the whole infection time. The expression of XAC1208 was ambiguous compared to the control; for example, its expression was upregulated at $12 \mathrm{~h}$, maintained at $20 \mathrm{~h}$ and 3 days, and downregulated at 5 days (Table 4). Analyses of the biological functions of the encoding proteins revealed their probable role in diverse cellular processes (Table 4). Sugar metabolism, wall degradation, and two-component regulation (TCS) were the least represented by these genes. A greater number of differentially expressed genes affected the type II secretion system and nucleic acid metabolism, and encoded hypothetical proteins (Table 4).

\begin{tabular}{|c|c|c|c|c|c|c|}
\hline Category* & Functional class* & $\begin{array}{l}\text { No. of } \\
\text { genes in } \\
\text { silico }\end{array}$ & $\begin{array}{l}\text { No. of differentially } \\
\text { expressed genes in } \\
\text { the macroarray }\end{array}$ & $\begin{array}{l}\% \text { of differentially } \\
\text { expressed genes in } \\
\text { relation to the genes } \\
\text { in silico }\end{array}$ & Upregulated & Downregulated \\
\hline $\mathrm{I}$ & Intermediary metabolism & 17 & 04 & 23.5 & 02 & 02 \\
\hline II & Biosynthesis of small molecules & 09 & 02 & 22.2 & 00 & 02 \\
\hline III & Macromolecule metabolism & 06 & 03 & 50.0 & 01 & 02 \\
\hline IV & Cell structure & 01 & 01 & 100 & 00 & 01 \\
\hline $\mathrm{V}$ & Cellular processes & 05 & 05 & 100 & 01 & 02 \\
\hline VI & Mobile genetic elements & 01 & 00 & 0.0 & 00 & 00 \\
\hline$\overline{\mathrm{VII}}$ & $\begin{array}{l}\text { Pathogenicity, virulence and } \\
\text { adaptation }\end{array}$ & 20 & 06 & 30.0 & 04 & 02 \\
\hline VIII & Hyphotetical & 42 & 12 & 28.5 & 04 & 09 \\
\hline IX & ORFs with undefined category & 03 & 01 & 33.3 & 01 & 00 \\
\hline TOTAL & & 104 & 32 & 30.7 & - & - \\
\hline
\end{tabular}

*According to genome annotation of the Xac bacterium.

\section{Validation of macroarray analysis through semi-quantitative RT-PCR}

The macroarray results were validated by analyzing three differentially expressed genes (XAC0398, XAC0416, and XAC2370) by semi-quantitative RT-PCR, using rDNA16S as a constitutively expressed gene. The results of quantitative Southern blot analysis (Figure 1) showed that all three genes presented the same expression profile observed in the macroarray experiment (Table 4). As expected, the expression of rDNA16S remained unaltered (Figure 1). 
Table 4. Differentially expressed genes in 'Pêra' sweet orange [Citrus sinensis (L.) Osbeck] during infection with Xanthomonas citri subsp citri (Xac).

\begin{tabular}{|c|c|c|c|c|c|c|c|}
\hline \multirow[t]{2}{*}{$\begin{array}{l}\text { Functional } \\
\text { class }\end{array}$} & \multirow[t]{2}{*}{ ORF $^{1}$} & \multicolumn{4}{|c|}{$\begin{array}{c}\text { Differential expression along the } \\
\text { infection kinetic }\end{array}$} & \multirow[t]{2}{*}{ Gene product } & \multirow[t]{2}{*}{ NCBI gene ID $^{2}$} \\
\hline & & $12 \mathrm{~h}$ & $20 \mathrm{~h}$ & 3 d.a.i. ${ }^{3}$ & 5 d.a.i. & & \\
\hline \multirow[t]{6}{*}{ A } & XAC0398 & 2.29 & 3.30 & 3.52 & 4.28 & HrpD6 protein & 1154469 \\
\hline & XAC0416 & 7.04 & 7.22 & 14.02 & 16.55 & Hpa1 protein & 1154487 \\
\hline & XAC2922 & & 1.29 & 2.25 & 1.28 & HrpW protein & 1156993 \\
\hline & $\mathrm{XAC} 0417$ & & & & 1.98 & Hpa2 protein & 1154488 \\
\hline & XAC1208 & 1.01 & & & -0.55 & XopP protein* & 1155279 \\
\hline & XAC0404 & & & & -2.73 & HpaP protein & 1154475 \\
\hline \multirow[t]{3}{*}{$\mathrm{B}$} & XAC0360 & 1.75 & 2.12 & 2.81 & 2.88 & Glycerol-3-phosphate dehydrogenase & 1154431 \\
\hline & XAC1375 & & 1.10 & 0.70 & 0.97 & Cyclopropane-fatty-acyl-phospholipid synthase & 1155446 \\
\hline & XAC0781 & & -0.60 & -0.98 & & D-alanine--D-alanine ligase B & 1154852 \\
\hline $\mathrm{C}$ & XAC1435 & 0.99 & 0.47 & & & TonB-dependent iron receptor & 1155506 \\
\hline $\mathrm{D}$ & XAC4258 & 0.94 & & & & Xylosidase/arabinosidase & $\underline{1158329}$ \\
\hline $\mathrm{E}$ & XAC1797 & & & 0.99 & & Two-component system, regulatory protein & 1155868 \\
\hline $\mathrm{F}$ & XAC0424 & & 2.12 & 2.24 & 2.05 & Cyclic diguanylate (GGDEF domain)* & 1154495 \\
\hline \multirow[t]{7}{*}{ G } & $\mathrm{XAC} 1330$ & -1.26 & & & & Putative adenylate cyclase family protein* & 1155401 \\
\hline & XAC4074 & -1.56 & -1.72 & -1.53 & -1.94 & Ribonucleoside-diphosphate reductase beta chain & 1158145 \\
\hline & $\mathrm{XAC} 2521$ & & & -1.15 & -0.99 & Uracil phosphoribosyltransferase & 1156592 \\
\hline & $\mathrm{XAC} 1511$ & & -1.36 & -1.58 & -1.63 & TmRNA & 1155582 \\
\hline & $\mathrm{XAC} 2513$ & & & -2.31 & -2.05 & Queuine rRNA-ribosyltransferase & 1156584 \\
\hline & $\mathrm{XAC} 2972$ & & -0.91 & -2.01 & -1.63 & RNA polymerase sigma-54 factor & 1157043 \\
\hline & $\mathrm{XAC} 1224$ & & & -1.14 & -0.98 & Cell division topological specificity factor & 1155295 \\
\hline $\mathrm{H}$ & XAC4292 & -2.21 & -1.61 & & -0.96 & Benzoate transporter & 1158363 \\
\hline \multirow[t]{2}{*}{ I } & $\mathrm{XAC} 1535$ & & -1.08 & & & Oxoglutarate dehydrogenase & 1155606 \\
\hline & XAC2727 & & -1.88 & -1.52 & -2.11 & Putative SCO1/SenC family protein* & 1156798 \\
\hline $\mathrm{J}$ & $\mathrm{XAC} 2370$ & & 1.29 & 2.13 & 2.49 & Putative secreted protein* & 1156441 \\
\hline $\mathrm{K}$ & XAC3309 & & & -1.36 & -1.46 & Aminopeptidase & 1157380 \\
\hline \multirow[t]{7}{*}{$\mathrm{L}$} & $\mathrm{XAC0315}$ & & 1.13 & 0.88 & 0.79 & Hypothetical protein & 1154386 \\
\hline & XAC1223 & -2.80 & & & & Hypothetical protein & 1155294 \\
\hline & XAC2827 & & -0.97 & -1.89 & -1.56 & Hypothetical protein & 1156898 \\
\hline & XAC1563 & & -0.86 & & -0.81 & Hypothetical protein & 1155634 \\
\hline & XAC1566 & & -1.96 & & -1.50 & Hypothetical protein & 1155636 \\
\hline & $\mathrm{XAC} 1817$ & & & -1.05 & -0.93 & Hypothetical protein & 1155888 \\
\hline & XAC2490 & & & -1.84 & -1.73 & Hypothetical protein & 1156561 \\
\hline
\end{tabular}

Values in the columns referring to the infection kinetics correspond to the level of expression of each gene (M value, 26 ) at the time of infection. Positive values correspond to gene induction and negative values to gene repression. No value means there was no difference in expression compared to bacterium growth in Nutrient Broth. 'Open-reading frame, according to genome annotation of the Xac bacterium (http://genoma4.fcav.unesp.br/xanthomonas/). ${ }^{2} \mathrm{As}$ described in GenBank, ${ }^{3}$ d.a.i. $=$ days after inoculation, * Re-annotation in this study, A = Type III secretion system; $\mathrm{B}=$ membrane and cell wall metabolism; $\mathrm{C}=$ iron caption system; $\mathrm{D}=$ sugars and wall degradation metabolism; $\mathrm{E}=$ signal transduction or two-component system; $\mathrm{F}=$ flagellum, biofilm, and adhesiveness; $\mathrm{G}=$ nucleic acid metabolism; $\mathrm{H}=$ membrane transport; $\mathrm{I}=$ energy metabolism; $\mathrm{J}=$ putative secreted proteins; $\mathrm{K}=$ others; and $\mathrm{L}=$ hypothetical. NCBI, National Center for Biotechnology Information.

\section{Validation of macroarray analysis through gene reporter assay}

The macroarray results were additionally validated using GUS as the gene reporter and the predicted PIP-box region as the promoter. Therefore, the PIP-box regions of XAC0416 and XAC0424 were tested, and the results presented in Table 5.

The Xac 306 strain alone showed no GUS activity. On the other hand, the pHMGUS0416- and pHMGUS0424-transformed Xac 306 constructs showed residual GUS activity in the neutral (NB) and induction (XAM1) medium. However, pHMGUS0416 Xac 306 showed a 2.8- and 4.4-fold increase in GUS activity 3 and 5 days after plant inoculation, 
respectively, while Xac containing the pHMGUS0424 construct showed a threefold increase in GUS activity 3 to 5 days after inoculation. We also observed an obvious difference in the GUS enzyme activity in Xac containing the pHMGUS0416 or pHMGUS0424 constructs 5 days after inoculation. In fact, the GUS activity induced by the XAC0416 promoter was ten times higher than that induced by the XAC0424 promoter.

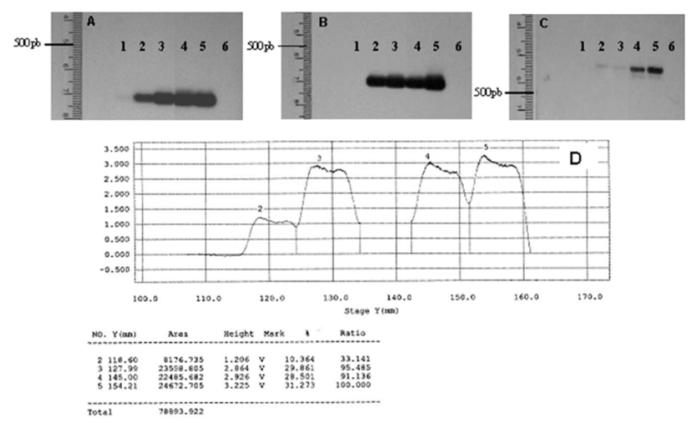

Figure 1. Southern blot of the results of semi-quantitative reverse transcriptase polymerase chain reaction (RTPCR) amplification of the open-reading frames XAC0398 (A), XAC0416 (B), and XAC2370 (C), obtained on an autoradiography film. Columns 1 to 6 correspond to Xac cultured under the following conditions: 1 = grown in NB medium; 2 = grown for $12 \mathrm{~h}$ in XAM1 medium; 3 = grown for $20 \mathrm{~h}$ in XAM1 medium; 4 = exudated from citrus leaves 3 days after inoculation; $5=$ exuded from leaves 5 days after inoculation; and $6=$ negative control. The visualized fragments are: A. 209 bp, B. 302 bp, and C. 942 bp in size. D. Autoradiography density was generated by the densitometer (CS-9301; Shimadzu) through hybridization of the nylon membrane containing $X$. axonopodis pv. citri total RNA cultured under different conditions, using probe specific for the ORF XAC0398.

Table 5. Absorbance of enzymatic reactions of wild-type Xac (306) or Xac containing the pHMGUS0416, pHMGUS0424, pHMGUS, or pHMGUS500 constructs and $\beta$-glucuronidase (GUS) activity estimate.

\begin{tabular}{|c|c|c|}
\hline Experimental condition & Time of reading $(\mathrm{min})$ & GUS activity $\left(\mathrm{OD}_{600}\right) / \mathrm{min}$ \\
\hline Xac::pHMGUS0416 (CN20 h) & 60 & $0.0062 \pm 0.045$ \\
\hline Xac::pHMGUS0416 (XAM1 20 h) & 60 & $0.0066 \pm 0.045$ \\
\hline Xac::pHMGUS0416 (3 d.a.i.) & 30 & $0.0199 \pm 0.016$ \\
\hline Xac::pHMGUS0416 (5 d.a.i.) & 30 & $0.0307 \pm 0.105$ \\
\hline Xac::pHMGUS0424 (CN 20 h) & 60 & $0.0005 \pm 0.002$ \\
\hline Xac::pHMGUS0424 (XAM1 20 h) & 60 & $0.0010 \pm 0.035$ \\
\hline$\overline{X a c: \text { pHMGUS0424 (3 d.a.i.) }}$ & 60 & $0.0026 \pm 0.019$ \\
\hline Xac::pHMGUS0424 (5 d.a.i.) & 60 & $0.0030 \pm 0.015$ \\
\hline$\overline{X a c:: p H M G U S ~(C N ~} 20 \mathrm{~h})$ & 60 & $0.0018 \pm 0.016$ \\
\hline Xac::pHMGUS (XAM1 $20 \mathrm{~h}$ ) & 60 & $0.0004 \pm 0.007$ \\
\hline Xac::pHMGUS (3 d.a.i.) & 30 & $0.0174 \pm 0.021$ \\
\hline$\overline{X a c: \text { pHMGUS (5 d.a.i.) }}$ & 30 & $0.0182 \pm 0.017$ \\
\hline Xac::pHMGUS500 (CN 20 h) & 60 & $0.0000 \pm 0.003$ \\
\hline Xac::pHMGUS500 (XAM1 $20 \mathrm{~h})$ & 60 & $0.0000 \pm 0.002$ \\
\hline Xac::pHMGUS500 (3 d.a.i.) & 60 & $0.0000 \pm 0.001$ \\
\hline Xac::pHMGUS500 (5 d.a.i.) & 60 & $0.0000 \pm 0.001$ \\
\hline$(\mathrm{B}+\mathrm{S})+$ Xac 306 strain wild type (NB $20 \mathrm{~h})$ & 120 & $0.0000 \pm 0.001$ \\
\hline$(\mathrm{B}+\mathrm{S})+$ Xac 306 strain wild type (XAM1 $20 \mathrm{~h})$ & 120 & $0.0000 \pm 0.001$ \\
\hline$(\mathrm{B}+\mathrm{S})+X a c 306$ strain wild type (3 d.a.i.) & 120 & $0.0000 \pm 0.001$ \\
\hline$(\mathrm{B}+\mathrm{S})+\mathrm{Xac} 306$ strain wild type (5 d.a.i.) & 120 & $0.0000 \pm 0.006$ \\
\hline (B) = blank & $30-120$ & 0.0000 \\
\hline$(\mathrm{B}+\mathrm{S})$ & $30-120$ & 0.0000 \\
\hline
\end{tabular}

NB $20 \mathrm{~h}=$ Xac grown in NB medium for $20 \mathrm{~h}$, XAM1 $20 \mathrm{~h}=$ Xac grown in XAM1 inductor medium for $20 \mathrm{~h}$, 3 D.A.I. $=X a c$ exuded from orange tree leaves 3 days after inoculation, 5 D.A.I. $=X a c$ exuded from orange tree leaves 5 days after inoculation $(B)=X$-gluc buffer, $(B+S)=X$-gluc buffer $+X$-gluc substrate. 
The promoterless pHMGUS construct (negative control) showed GUS enzymatic activity at all studied times. Similar results were obtained by Furutani et al. (2006), using the same reporter gene system, wherein the empty vector construct (promoterless gus gene) showed GUS activity. However, the insertion of a non-promoter 500-bp DNA spacer fragment between the lac promoter of the pHM1 vector and the gus reporter gene did not induce substrate (X-gluc) degradation in Xac cells transformed with pHMGUS500. Therefore, PIP-box regions from both XAC0416 and XAC0424 functioned as promoters when Xac was grown in medium mimicking the host plant, or within the host itself.

\section{DISCUSSION}

Herein, we aimed to identify novel Xac genes regulated by PIP-box and PIP-boxrelated sequences during bacterial growth in virulence-inducing medium (in vitro) and in planta, after citrus host infection, thereby correlating them with putative pathogenicity and virulence functions underlying citrus canker.

Thirty-two of the 104 genes identified by macroarray analysis were deemed to be differentially expressed. Among these, 26 presented the perfect PIP consensus sequence TTCGC....N15....TTCGC, 63 expressed the imperfect PIP sequence TTCGD....N15.... TTCGD (D could represent A, T, or G), while the remaining 15 presented the imperfect PIP sequence TTCGC....N16....TTCGC. Functional categorization revealed the involvement of these genes in several biological processes discussed herein.

Among the 32 differentially expressed genes possessing a PIP-box motif, 12 were upregulated and 19 were downregulated. Only one gene displayed a hybrid behavior, showing an increased or decreased expression at specific infection times. In this study, we used a modified inducing media, designated XAM1, derived from modifications made to the XVM2 medium; this medium proved to be a better inducer of the hrp gene in Xanthomonas citri subsp citri (Xac) than XVM2 (seen in previous experiments; personal communication with F.F. White). Therefore, we concluded that the culture parameters of XAM1 could be specific for the induction of Xac, by conferring similar conditions as the citric host, compared to the $\mathrm{XVM} 2$ broth, which is usually used to induce Xanthomonas campestris pv. vesicatoria.

Previously, Occhialini et al. (2005) studied gene expression in a $R$. solanacearum genome microarray; the $h r p$ promoters of this phytopathogen are regulated by the transcriptional activator HrpB (homologous to HrpX in Xanthomonas), and are therefore identified as HrpBdependent genes. One hundred and forty-three of these genes were upregulated, while 50 were downregulated through $h r p B$. As seen in the study on $R$. solanacearum, the results of this study allowed the identification of up- or downregulated genes in Xac submitted to in vitro or in vivo virulence induction, related or unrelated to the type III secretion system.

\section{Type III secretion system}

The pathogenicity and virulence of Xac are determined by TTSS functioning, which is highly conserved in plant pathogenic gram-negative bacteria (Büttner and Bonas, 2002). We verified that at least six of the differentially expressed genes (XAC0398, XAC0404, XAC0416, XAC0417, XAC1208, and XAC2922) identified during infection kinetics are TTSS effector and structural protein encoders (Table 4). The presence of this system allows the pathogen, once adhered to the host cell surface, to initiate its virulent function by injecting proteins to the host cell cytoplasm. The results of this study are in agreement with data provided in the literature. 


\section{Cell wall and membrane metabolism}

The expression of three genes related to bacterial cell wall and membrane metabolism was modified (XAC0360, XAC1375, and XAC0781; Table 4). The expression of the cyclopropanate fatty acid synthase coding gene (XAC1375) was upregulated during the early stages of infection $(20 \mathrm{~h})$, and remained in this state up to 5 days after infection; this precluded cyclopropanation of the cell envelope membrane phospholipids, a phenomenon also observed in Mycobacterium during resistance to oxidative stress (Yuan et al., 1995). Moreover, this mechanism is critical for infection initiation in mice (Rao et al., 2005). The results of this study indicated a re-architecture of the macro-molecular structures (Lång, 2000) affecting the Xac::citrus interaction. This allows the proteins to anchor to bacterial cell membrane, in turn facilitating adherence to, and interaction with, the host cells, and consequently, successful induction of disease.

\section{Iron uptake}

The TonB-dependent receptor (XAC1435) expression was induced during the Xachost interaction (Table 4). These receptors recognize siderophore molecules, which can reduce $\mathrm{Fe}^{3+}$ to $\mathrm{Fe}^{2+}$; therefore, we deduced that the genes encoding these receptors could play a major role in iron absorption by bacteria. This is important because iron is essential for bacterial metabolism, with functions in processes like respiration, RNA synthesis, and inactivation of reactive oxygen species (Wandersman and Delepelaire, 2004).

\section{Plant cell-wall degrading enzymes}

A major challenge faced by Xac is the lack availability of nutrients required for multiplication in the apoplastic spaces of the host. Xac overcomes this challenge by promoting plant cell wall degradation through hydrolase-type celullases, pectinases, and glycosidases (Wang et al., 2008). In this study, we observed an early upregulation of genes encoding a predicted xylosidase/arabinosidase (XAC4258) and pectate lyase (XAC2922) (12 and $20 \mathrm{~h}$ after growth on inducing XAM1 medium, respectively; Table 4), which could be involved in the attachment and degradation of host plant cell wall polysaccharides, in order to feed the attacking pathogen.

\section{Two-component system}

Prokaryotic two-component or transduction systems are often part of complex regulatory networks and cascades. They are of paramount importance in transmitting environmental signals and regulating adaptive responses. In general, these systems comprise a sensor protein and a response regulator protein. The conserved domain of the sensor class is usually located at the C-terminus of the protein, while the regulator class is located at the N-terminus of the protein. The sensor proteins are histidine protein kinases that autophosphorylate during direct or indirect response to environmental stimuli, subsequently transferring the phosphate to a specific aspartate residue of the response regulator protein. Phosphorylation of the response regulator protein modifies its regulatory function (Albright et al., 1989; Charles et al., 1992). The X. oryzae pv. oryzae PhoPQ two-component system has 
a role in virulence and in the production of the AvrXA21 avirulence protein, in collaboration with the RaxRH two-component system. RaxRH regulates the expression of eight rax genes (required for $A \mathrm{vr} X \mathrm{~A} 21$ activity), in order to sense the population cell density (Lee et al., 2008).

The expression of genes encoding regulatory proteins of the two-component system is altered when the bacteria comes in contact with the plant (XAC1797; Table 4). The XAC1797 gene codes for a response regulator protein within the PrrA domain (HTH_8). Laguri et al. (2006) reported PrrA to be a transcription regulator activated upon phosphorylation by its cognate kinase PrrB in response to low oxygen levels in Rhodobacter sphaeroides.

One hypothesis could be that this protein, encoded by the XAC1797 gene, can be a part of a two-component system that responds to the host plant contact, in addition to environmental signals, and regulates virulence genes. This hypothesis could be verified in the future through protein-protein interaction assays in yeast, using a two-hybrid system.

\section{Motility and adhesiveness}

In general, microorganisms can perceive environmental changes, thereby triggering the expression of protein-encoding genes, facilitating their maintenance and multiplication in the new environment. These proteins include hemagglutinins, proteins with GGDEF (GlyGly-Asp-Glu-Phe) domains, and proteins related to flagellum biogenesis. In this study, we verified the induction of a gene associated with the synthesis of a protein initially considered hypothetical, and later re-annotated in this study as a putative diguanylate cyclase (XAC0424), belonging to the group of proteins containing a GGDEF domain (Table 4).

\section{Nucleic acid metabolism}

We also verified the repression of seven genes related to basal metabolism of nucleic acids when the pathogen was in the host plant environment and in a culture medium mimicking this environment (XAM1) (XAC1330, XAC4074, XAC2521, XAC1511, XAC2513, XAC2972, and XAC1224; Table 4). In this experiment, the control sample consisted of bacterium grown in NB medium, as opposed to bacterium grown under nutrient restriction conditions in the XAM1 inductive medium or in the plant; therefore, the obtained results suggested that the basal metabolism of nucleic acids (nucleotide synthesis, replication, and transcription) was higher under nutrient abundance. Upon installing itself in the intercellular spaces of the plant, the bacterium executes a series of adaptive mechanisms to colonize the environment. These adaptive measures should lead to slower cell multiplication, as opposed to bacterial development in rich culture medium.

\section{Membrane transporters}

Many studies on pathogenic microorganisms report the importance of membrane transport proteins (ATP-binding cassette families and major facilitator superfamily) in the toxic (to the pathogen) efflux of the host, which protect the pathogens from this line of defense (Pao et al., 1998; Schoonbeek et al., 2003; Zwiers et al., 2003). However, this transport system is also involved in the influx of a number of biological molecules, including sugars, lipids, and polysaccharides. Therefore, the observed repression of genes encoding components related to substance transport (XAC4292, Table 4) could be correlated with differences in 
the environment, such as those between the NB medium and the initial host environmental conditions. We cannot exclude the hypothesis that this gene can be activated during the necrotic phase of the disease ( 5 days after infection), when the massive degradation of vegetal cell compounds, and eventual lysis of the cell, can lead to the release of substances that are toxic to the pathogen.

\section{Energy metabolism}

We verified the repression of two genes (XAC1535 and XAC2727; Table 4) involved in energy metabolism during the course of infection. The results of this study suggested that bacteria grown in XAM1 medium and in planta metabolize a lower amount of bioenergy during the infecting stage than bacterium grown in the NB medium.

\section{Putative secreted proteins}

The differential expression of XAC2370 (Table 4), annotated as coding for a hypothetical protein, was verified. When submitted to BLASTp analysis, the encoding protein showed homology with the putative secreted proteins of Xcv.

\section{Hypothetical proteins}

Seven $(37.5 \%)$ of the thirty-two differentially expressed genes coded for hypothetical proteins that were differentially expressed during the infection stage; therefore, these proteins could be further analyzed for their role in Xac pathogenicity and virulence.

\section{CONCLUSIONS}

The DNA macroarray technique was used in this gene expression study; we identified 32 differentially expressed genes related to different cellular processes, such as the processes involved in the Xac type III secretion system (XAC0398, XAC0404, XAC0416, XAC0417, $\mathrm{XAC1208}$, and XAC2922). This allows the pathogen to initiate virulence once adhered to the host cell surface by injecting proteins to the host cell cytoplasm. Moreover, the differential expression of these genes leads to the modification of other mechanisms such as membrane and cell wall metabolism (XAC0360, XAC1375, and XAC0781); anchoring of host (citrus plant) proteins to the bacterial (Xac) cell membrane, thereby promoting adherence and interaction among the host cells and consequent successful induction of disease; bacterial iron uptake (XAC1435), which is of major importance because iron is essential for bacterial metabolism; sugar metabolism and cell wall degradation (XAC4258 and XAC2922), responsible for the attachment and degradation of the host plant cell wall polysaccharides to feed the attacking pathogen; and signal transduction (XAC1797; this gene is part of a two-component system that responds to host plant contact). Other differentially expressed genes are involved in flagellum metabolism, biofilm formation and adhesiveness (XAC0424), nucleic acid metabolism (XAC1330, XAC4074, XAC2521, XAC1511, XAC2513, XAC2972, and XAC1224), membrane transport (XAC4292), and energy metabolism (XAC1535 and XAC2727).

We also confirmed that PIP-box promoters play major roles in mediating the gene expression in Xanthomonas citri subsp citri, indicating that this could lead to the induction or 
repression of gene expression, allowing the establishment of the pathogen onto the host plant from the time of interaction.

Further evidence of this role has been provided by the results of reporter gene assays, wherein some promoters responded to gene induction when in contact with the host plant.

Together, these results shed a new light on the importance of PIP-box promoters on the ability of the pathogen to induce citrus canker.

\section{Conflicts of interest}

The authors declare no conflict of interest.

\section{ACKNOWLEDGMENTS}

Research supported by grants from Fundação de Amparo à Pesquisa do Estado de São Paulo (FAPESP) and Coodernação de Aperfeiçoamento de Pessoal de Nível Superior (CAPES).

\section{REFERENCES}

Agrios NG (2005). Plant Pathology. 5th edn. Elsevier Academic Press, Burlington, MA.

Albright LM, Huala E and Ausubel FM (1989). Prokaryotic signal transduction mediated by sensor and regulator protein pairs. Аnпи. Rev. Genet. 23: 311-336. http://dx.doi.org/10.1146/annurev.ge.23.120189.001523

Benjamini Y and Hochberg Y (1995). Controlling the false discovery rate: a practical and powerful approach to multiple testing. J.R. Stat. Soc. 57: 289-300.

Brown K (2001). Florida fights to stop citrus canker. Science 292: 2275-2276. http://dx.doi.org/10.1126/ science.292.5525.2275

Büttner D and Bonas U (2002). Getting across - bacterial type III effector proteins on their way to the plant cell. EMBO J. 21: 5313-5322.http://dx.doi.org/10.1093/emboj/cdf536

Charles TC, Jin S and Nester EW (1992). Two-component sensory transduction systems in phytobacteria. Annu. Rev. Phytopathol. 30: 463-484.http://dx.doi.org/10.1146/annurev.py.30.090192.002335

Ciesiolka LD, Hwin T, Gearlds JD, Minsavage GV, et al. (1999). Regulation of expression of avirulence gene avrRxv and identification of a family of host interaction factors by sequence analysis of avrBsT. Mol. Plant Microbe Interact. 12: 35-44. http://dx.doi.org/10.1094/MPMI.1999.12.1.35

Cunnac S, Boucher C and Genin S (2004). Characterization of the cis-acting regulatory element controlling HrpBmediated activation of the type III secretion system and effector genes in Ralstonia solanacearum. J. Bacteriol. 186: 2309-2318. http://dx.doi.org/10.1128/JB.186.8.2309-2318.2004

Da Silva ACR, Ferro JA, Reinach FC, Rarah CS, et al. (2002). Comparison of the genomes of two Xanthomonas pathogens with differing host specificities. Nature 417: 459-463.

Fenselau S and Bonas U (1995). Sequence and expression analysis of the hrpB pathogenicity operon of Xanthomonas campestris pv. vesicatoria which encodes eight proteins with similarity to components of the Hrp, Ysc, Spa, and Fli secretion systems. Mol. Plant Microbe Interact. 8: 845-854.http://dx.doi.org/10.1094/MPMI-8-0845

Figueiredo JFL, Minsavage GV, Graham JH and White FF (2011). Mutational analysis of type III effector genes from Xanthomonas citri subsp. citri. Eur. J. Plant Pathol. 130: 339-347. http://dx.doi.org/10.1007/s10658-011-9757-7

Frisch DA, Harris-Haller LW, Yokubaitis NT, Thomas TL, et al. (1995). Complete sequence of the binary vector Bin 19. Plant Mol. Biol. 27: 405-409. http://dx.doi.org/10.1007/BF00020193

Furutani A, Nakayama T, Ochiai H, Kaku H, et al. (2006). Identification of novel HrpXo regulons preceded by two cis-acting elements, a plant-inducible promoter box and a -10 box-like sequence, from the genome database of Xanthomonas oryzae pv. oryzae. FEMS Microbiol. Lett. 259: 133-141.http://dx.doi.org/10.1111/j.1574-6968.2006.00265.x

Gentleman RC, Carey VJ, Bates DM, Bolstad B, et al. (2004). Bioconductor: open software development for computational biology and bioinformatics. Genome Biol. 5: R80. http://dx.doi.org/10.1186/gb-2004-5-10-r80

Guo W, Cui YP, Li YR, Che YZ, et al. (2012a). Identification of seven Xanthomonas oryzae pv. oryzicola genes potentially involved in pathogenesis in rice. Microbiology 158: 505-518. http://dx.doi.org/10.1099/mic.0.050419-0 
Guo W, Cai LL, Zou HS, Ma WX, et al. (2012b). Ketoglutarate transport protein KgtP is secreted through the type III secretion system and contributes to virulence in Xanthomonas oryzae pv. oryzae. Appl. Environ. Microbiol. 78: 56725681.http://dx.doi.org/10.1128/AEM.07997-11

Huber W, von Heydebreck A, Sültmann H, Poustka A, et al. (2002). Variance stabilization applied to microarray data calibration and to the quantification of differential expression. Bioinformatics 18 (Suppl 1): S96-S104.http://dx.doi. org/10.1093/bioinformatics/18.suppl_1.S96

Huguet E and Bonas U (1997). hrpf of Xanthomonas campestris pv. vesicatoria encodes an 87-kDa protein with homology to NoIX of Rhizobium fredii. Mol. Plant Microbe Interact. 10: 488-498. http://dx.doi.org/10.1094/ MPMI.1997.10.4.488

Ihaka R and Gentleman RCR (1996). A language for data analysis and graphics. J. Comput. Graph. Stat. 5: 299-314.

Innes RW, Hirose MA and Kuempel PL (1988). Induction of nitrogen-fixing nodules on clover requires only 32 kilobase pairs of DNA from the Rhizobium trifolii symbiosis plasmid. J. Bacteriol. 170: 3793-3802.

Koebnik R, Krüger A, Thieme F, Urban A, et al. (2006). Specific binding of the Xanthomonas campestris pv. vesicatoria AraC-type transcriptional activator HrpX to plant-inducible promoter boxes. J. Bacteriol. 188: 7652-7660. http:// dx.doi.org/10.1128/JB.00795-06

Lacorte C (1998). $\beta$-Glucuronidase (GUS). In: Manual de Transformação Genética de Plantas (Brasileiro ACM and Carneiro VTC, eds.). Embrapa-SPI/Embrapa-Cenargen, Brasília, 127-141.

Laguri C, Stenzel RA, Donohue TJ, Phillips-Jones MK, et al. (2006). Activation of the global gene regulator PrrA (RegA) from Rhodobacter sphaeroides. Biochemistry 45: 7872-7881.http://dx.doi.org/10.1021/bi060683g

Lång H (2000). Outer membrane proteins as surface display systems. Int. J. Med. Microbiol. 290: 579-585. http://dx.doi. org/10.1016/S1438-4221(00)80004-1

Lee SW, Jeong KS, Han SW, Lee SE, et al. (2008). The Xanthomonas oryzae pv. oryzae PhoPQ two-component system is required for AvrXA21 activity, hrpG expression, and virulence. J. Bacteriol. 190: 2183-2197. http://dx.doi. org/10.1128/JB.01406-07

Occhialini A, Cunnac S, Reymond N, Genin S, et al. (2005). Genome-wide analysis of gene expression in Ralstonia solanacearum reveals that the $h r p B$ gene acts as a regulatory switch controlling multiple virulence pathways. Mol. Plant Microbe Interact. 18: 938-949. http://dx.doi.org/10.1094/MPMI-18-0938

Pao SS, Paulsen IT and Saier MH, Jr. (1998). Major facilitator superfamily. Microbiol. Mol. Biol. Rev. 62: 1-34.

Rao V, Fujiwara N, Porcelli SA and Glickman MS (2005). Mycobacterium tuberculosis controls host innate immune activation through cyclopropane modification of a glycolipid effector molecule. J. Exp. Med. 201: 535-543. http:// dx.doi.org/10.1084/jem.20041668

Salanoubat M, Genin S, Artiguenave F, Gouzy J, et al. (2002). Genome sequence of the plant pathogen Ralstonia solanacearum. Nature 415: 497-502. http://dx.doi.org/10.1038/415497a

Sambrook J, Fritsch EF and Maniatis T (1989). Molecular Cloning: a laboratory manual. 2nd edn. Cold Spring Harbor Laboratory Press, New York.

Sanger F, Nicklen S and Coulson AR (1977). DNA sequencing with chain-terminating inhibitors. Proc. Natl. Acad. Sci. USA 74: 5463-5467. http://dx.doi.org/10.1073/pnas.74.12.5463

Schoonbeek HJ, Van Nistelrooy JGM and Waard MA (2003). Functional analysis of ABC transporter genes from Botrytis cinerea identifies BcatrB as a transporter of eugenol. Eur. J. Plant Pathol. 109: 1003-1011. http://dx.doi.org/10.1023/ B:EJPP.0000003936.61182.14

Schummer M, Ng WV, Bumgarner RE, Nelson PS, et al. (1999). Comparative hybridization of an array of 21,500 ovarian cDNAs for the discovery of genes overexpressed in ovarian carcinomas. Gene 238: 375-385. http://dx.doi. org/10.1016/S0378-1119(99)00342-X

Smyth GK (2005). Limma: linear models for microarray data. In. Bioinformatics and computational biology solutions using R and bioconductor (Gentleman R, Carey V, Dudoit S, Irizarry R and Huber W, eds.). Springer, New York, $397-420$.

Tai YC and Speed TP (2006). A multivariate empiriacal bayes statistic for replicated microarray time course data. Ann. Stat. 34: 2387-2412. http://dx.doi.org/10.1214/009053606000000759

Wandersman C and Delepelaire P (2004). Bacterial iron sources: from siderophores to hemophores. Annu. Rev. Microbiol. 58: 611-647. http://dx.doi.org/10.1146/annurev.micro.58.030603.123811

Wang L, Rong W and He C (2008). Two Xanthomonas extracellular polygalacturonases, PghAxc and PghBxc, are regulated by type III secretion regulators $\mathrm{HrpX}$ and $\mathrm{HrpG}$ and are required for virulence. Mol. Plant Microbe Interact. 21: 555-563.http://dx.doi.org/10.1094/MPMI-21-5-0555

Wengelnik K and Bonas U (1996). HrpXv, an AraC-type regulator, activates expression of five of the six loci in the hrp cluster of Xanthomonas campestris pv. vesicatoria. J. Bacteriol. 178: 3462-3469. 
Yuan Y, Lee RE, Besra GS, Belisle JT, et al. (1995). Identification of a gene involved in the biosynthesis of cyclopropanated mycolic acids in Mycobacterium tuberculosis. Proc. Natl. Acad. Sci. USA 92: 6630-6634.http://dx.doi.org/10.1073/ pnas.92.14.6630

Zwiers LH, Stergiopoulos I, Gielkens MM, Goodall SD, et al. (2003). ABC transporters of the wheat pathogen Mycosphaerella graminicola function as protectants against biotic and xenobiotic toxic compounds. Mol. Genet. Genomics 269: 499-507. http://dx.doi.org/10.1007/s00438-003-0855-x

\section{Supplementary material}

S1 Table. 104 genes identification possibly controlled by PIP-box promoters. 